\title{
Working
}

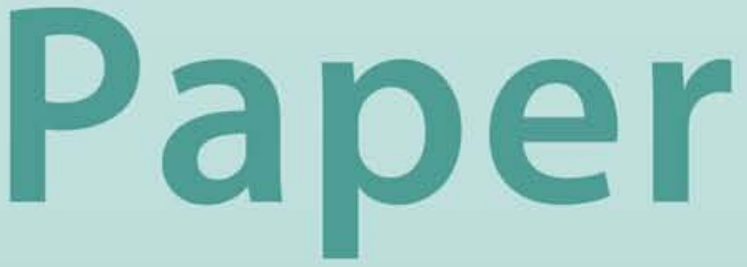




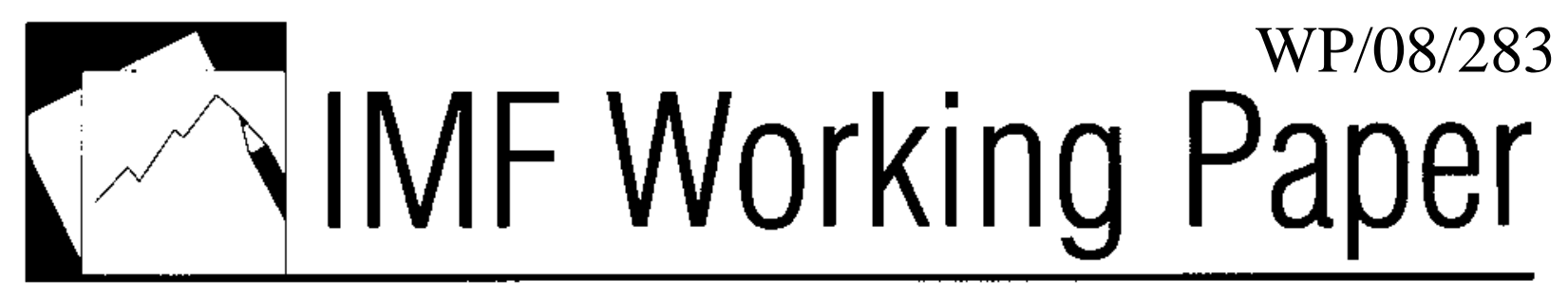

Cross-Border Coordination of Prudential Supervision and Deposit Guarantees

Daniel C. Hardy and Maria J. Nieto 


\title{
IMF Working Paper
}

Monetary and Capital Markets Department

\section{Cross-Border Coordination of Prudential Supervision and Deposit Guarantees}

\author{
Prepared by Daniel C. Hardy and Maria J. Nieto ${ }^{1}$
}

Authorized for distribution by Daniel C. Hardy

December 2008

\begin{abstract}
This Working Paper should not be reported as representing the views of the IMF. The views expressed in this Working Paper are those of the author(s) and do not necessarily represent those of the IMF or IMF policy. Working Papers describe research in progress by the author(s) and are published to elicit comments and to further debate.

The scramble to expand deposit guarantees in Europe in response to recent financial turmoil confirms that the on-going integration of European financial markets requires closer coordination of prudential policies and financial safety nets. We study the optimal design of prudential supervision and deposit guarantee regulations in a multi-country, integrated banking market such as the European Union, where policy-makers have either similar or asymmetric preferences regarding profitability and stability of the banking sector. The paper concludes with recommendations on policy priorities in this area.

JEL Classification Numbers:F36, F59, G28

Keywords: Deposit guarantees, bank supervision, cross-border coordination, EU

Author’s E-Mail Address: dhardy@imf.org, maria.nieto@bde.es

\footnotetext{
${ }^{1}$ Daniel C. Hardy: International Monetary Fund; Maria J. Nieto: Banco de España. The authors gratefully acknowledge comments received from Martin Cihak, Jerry Dwyer, Bob Eisenbeis, David Parker, Alexander Tieman and Larry Wall. The views expressed in this paper are those of the authors and do not necessarily represent those of the Banco de España or those of the IMF or IMF policy.
} 


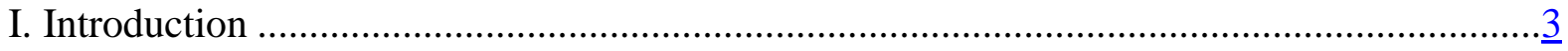

II. Relevant Academic Literature......................................................................................

III. Current Regulation of Supervision and Deposit Guarantees in the EU................................

IV. A Model of Supervisory and Deposit Guarantees Coordination ........................................... $\underline{9}$

V. Application to the Policy Debate in the EU and Conclusions ..............................................22

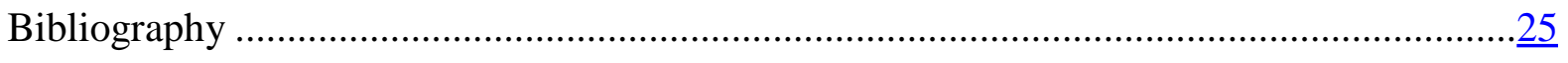

Figures

1. Net marginal welfare from supervision ………………................................................16

2. Optimal supervision and deposit guarantees................................................................... 


\section{INTRODUCTION}

The recent global financial crisis has demonstrated powerfully the interconnectedness of financial markets, the difficulties of cross-border coordination of prudential supervision and safety net arrangements, and the costs of poor preparation and international rivalry. Crossborder activity of European banks poses particular challenges. Banking sector integration is on-going — as witnessed by several major cross-border mergers the dominant role of western European banks in the new member states of the EU, and the operation of pan-European wholesale financial markets. Yet, supervisory systems and safety nets are still nationally based, and effective coordination mechanisms are still being developed. In the recent global financial turbulence, failures of large cross-border EU banks have already occurred,. Policymakers are considering how to achieve the best combination of mechanisms to reduce the probability of banking crises and deal effectively with the incidents that may occur, while also promoting the integration and efficiency of the European financial system. Thus far, the policy debate (and the literature) on the European Union (EU) financial sector stability framework have focused mainly on the coordination of prudential supervision and lender of last resort facilities. ${ }^{2}$ Relatively little attention has been paid recently to deposit guarantees and, more specifically, whether deposit guarantee provisions in different countries affect financial stability and how they interact with prudential supervision. ${ }^{3}$

This paper attempts to bridge this gap by exploring the optimal coordinated design of both deposit guarantees and prudential supervision in the EU. For the purpose of the paper, we use a broad definition of deposit guarantees that encompasses also the prospect of a government bail-out or the resolution of bank in crisis without significant cost to claimants. Our paper shows that, under certain assumptions, a relation exists between optimal level of prudential supervision and deposit guarantees. It also shows what are the optimal levels of each type of regulation in light of possible spill-overs in a multi-country setting in which country policymakers cooperate to various degrees, such as is the case in the EU. Our paper contributes to the theoretical underpinnings of the design of the financial sector stability framework and, more specifically, to an integrated approach to prudential and deposit guarantee regulation in the EU.

To this end, we adapt the model of Dell'Ariccia and Marquez (2001), where each policymaker aims to maximize expected welfare, which depends on both the profitability and the stability of the banking system which it oversees. However, there is a trade-off between the two objectives. Furthermore, there are externalities across countries (for example, the

\footnotetext{
${ }^{2}$ The stability framework encompasses prudential regulation, lender of last resort, deposit guarantees, and reorganization and winding up.

${ }^{3}$ We will use the term "deposit insurance" and "deposit guarantee" interchangeably. For concision, we will also use the terms "regulation" and "supervision" to encompass both activities.
} 
stability of the financial system in one country contributes to that in another) and therefore an incentive to cooperate. The multi-country setting of the model represents the decentralized decision-making in the EU, where harmonization and policy coordination through committees and memorandums of understanding (MoUs) aim at increasing internalization of decisions and policies in safeguarding EU financial stability (Nieto and Schinasi, 2007). In our paper, each policy-maker has two instruments, namely, the stringency of prudential regulation and supervision on the one hand, and the extent of deposit guarantee provision on the other. ${ }^{4}$ Prudential supervision is effective in making the financial system more stable, but it is costly. Anticipated deposit guarantees (or another de facto or de jure guarantee for claimants on a bank) increase the probability of a banking crisis by generating moral hazard, but, if a banking crisis occurs, the costs are reduced by the availability of guarantees. ${ }^{5}$ In this framework, we can define the optimal design of prudential supervision and deposit guarantee regulations in a multi-country integrated banking market such as the European Union, where policy-makers have either similar or asymmetric preferences.

Section two of the paper reviews some related academic literature. The third section reviews the regulation of prudential supervision and deposit guarantees in the EU. We present our model for prudential supervision and deposit guarantees in section four. In this section, we explore the different solutions both in the case of isolated countries as well as, in the case of countries that have integrated their financial systems where regulators' actions (or lack of action) on prudential supervision and deposit guarantees may spill over into other countries. More specifically, we explore the possibility that country policy-makers cooperate and take into consideration the spill-overs of supervision both in isolation and together with deposit guarantees. We discuss the applicability of our models to the present policy debate in the EU in the last section.

\section{RELEVANT ACADEMiC LiterATURE}

The incentives for prudential regulators to cooperate and the optimal design of regulation in a multi-country framework have drawn the attention of academics in recent years.

Dell'Ariccia and Marquez (2001) studied competition among prudential regulators in a multi-country setting. These authors studied how competition among regulators affects regulatory standards and which factors favor the emergence of "regulatory unions" among countries. The authors present a model where national regulators concerned with stability and profitability of their country’s banking system set their regulatory policies non-cooperatively,

\footnotetext{
${ }^{4}$ Dell'Ariccia and Marquez concentrate just on prudential regulation. In the rest of this paper, we will refer to prudential supervision to encompass the concepts of prudential regulation and its implementation through supervision.

${ }^{5}$ Moral hazard can be reduced by limiting the deposit guarantee, but that may reduce the effectiveness of the guarantee in forestalling runs.
} 
and establish conditions under which a centralized international regulator is more likely to emerge. The main conclusion is that in a setting of many countries with heterogeneous preferences, a centralized regulator will be preferred if such a regulator were to choose regulatory standards higher than those of the country with the highest individual standards. This will be the case when the negative impact of increased regulation for a regulator's own country is not too large (i.e., the impact on banks' profits of increasing prudential regulation does not overwhelm the benefits of greater stability).

Holthausen and Rønde (2005) analyze the information exchange between prudential supervisors in the EU, and show that, as long as the interests of the supervisors do not perfectly coincide, the host country supervisor does not reveal all the information that it possess. As a result, it is not possible to implement the first-best bank closure rule. The authors also show that the better aligned are the interests of the supervisors, the more detailed information can be exchanged and the higher is the welfare resulting from the closure decision. In this context, they propose a goal conflict resolution mechanism that relies on supranational supervision. The supranational supervisor has fewer possibilities for exploiting the information that it receives to its 'own' advantage than does the home country supervisor that is better informed than the hosts. This alleviates the incentive problems in the information exchange. The authors conclude that, even if there is no political consensus for creating a centralized supervisor in the EU, the centralized supervisor may still lead to better prudential supervision.

The incentives of supervisors to cooperate in a multi-country setting have been studied also by Freixas (2003), who shows that information asymmetries and country differences in prudential capabilities — such as what presently exists in Europe-will most likely lead to suboptimal decisions and outcomes that can be improved upon through cooperative decision making and centralized information. In a multi-country setting, the cost of a cross-border banking crisis would increase both because it requires ex post cooperation that may lead to inefficient rescues, and because it diminishes the incentives to collect accurate information ex ante. As a result, the optimal supervisory policy in a multi-country- setting has to be stricter. This finding is in line with those of Dell'Ariccia and Marquez (2001).

Kane (2002) argues that incumbent politicians and regulators do not necessarily respond to regulatory arbitrage by improving their regulatory systems. They may attempt, either instead or as well, to form cross-country regulatory cartels and to curtail industry criticism during their watch by offering their constituencies hard-to-observe supervisory and regulatory subsidies (e.g. more lenient solvency requirements). The speed and extent to which regulatory competition may lead to better regulation on average varies with the accountability design and political system within which a given regulatory culture is embedded. In Kane's view, this conclusion affirms the need to focus on regulatory incentives and to recognize differences in regulatory culture as a largely exogenous constraint on the problem of finding optimal ways to internalize deposit-guarantee externalities across countries. 
Deposit guarantees are generally seen as presenting a trade-off between the benefits that it yields in times of banking crisis and the moral hazard it engenders in normal times (see for example Garcia, 1999, or Barth, Caprio, and Levine, 2006). Once suspicions arise about the quality of a bank's assets, a deposit run may occur, even if the bank is in fact solvent The run may also spread to other banks which are viewed as vulnerable to contagion. If a bank

actually fails, the cost to society is magnified by the disruption to the availability of liquidity. The non-availability and possible loss of deposits consequent to a bank failure may be especially harmful to poorer and financially less sophisticated section of the population, who hold fewer alternative assets. These negative effects are diminished by the availability of deposit guarantees. Yet, the safety provided by deposit guarantees reduces the incentive for depositors to evaluate the soundness of the institutions where they place their money; deposit financing flows to banks independent of their riskiness. Furthermore, bank managers and owners have more incentive to undertake risky lending, since some of the downside risk is assumed by the deposit guarantees scheme. If the costs of a deposit guarantee scheme are partly met with taxpayers' money, the scheme should reduce banks' net funding costs, leading them to expand lending more than they would have otherwise.

The design of deposit guarantees and its effects on financial stability has been the subject of empirical research. Demirgüç-Kunt and Detragiache (2002) and Barth, Caprio, and Levine (2006) conclude that "more generous deposit insurance is associated with a higher probability of suffering a systemic banking crisis.” Demirgüç-Kunt and Huizinga (2004) find that deposit guarantees lowers deposit interests rates but also weakens market discipline. Laeven (2004), and Demirgüç-Kunt, Kane and Laeven (2006) find that deposit guarantee coverage is significantly higher in countries where poorly capitalized banks dominate the market and in countries where depositors are poorly educated. The latter's results suggest also that deposit guarantees subsidizes banks that are prepared to exploit weaknesses in supervisory risk control to extract value from taxpayers and safer banks. Thus, political economy considerations are important in the determination of deposit guarantees and prudential supervision. These considerations may gain in importance and complexity in a cross-country setting.

Although the literature on deposit guarantee schemes concentrates more on single-country settings, notable exemptions are Eisenbeis and Kaufman (2007), who propose principles to ensure the efficient resolution of EU cross-border banks, and Eisenbeis (2006), who associates the likely incident of systemic risk and the negative externalities with the bank resolution procedures (including deposit guarantee arrangements).

\section{CuRRENT REgulation OF SUPERVISION AND DEPOSIT GUARANTEES IN THE EU}

In the context of a decentralized decision making framework, EU policy makers have traditionally relied mainly on the setting of regulatory standards to achieve the integration of 
the financial markets of member states. ${ }^{67}$ The underlying rationale has been that regulation should support a level playing field between banks in different countries, thereby reducing opportunities for regulatory arbitrage and competition among regulators, but also ensuring that competition among financial institutions is not distorted. In effect, regulatory harmonization in the EU has set a lower bound on safety and soundness, and has made regulatory coordination possible among countries, although such coordination is, as explained below, imperfect.

The harmonization of bank regulation started in the EU in 1977. Banking Directives since then have established three broad types of principles: home country control; mutual recognition of supervisory authorities; and minimum requirements for authorizing banks as well as capital requirements and deposit guarantees. More specifically, the EU directives on solvency $^{8}$ and depositor protection ${ }^{9}$ were designed mainly with the aim of discouraging credit institutions within the EU from using different features of solvency requirements and depositor protection to compete unduly with each other or to circumvent regulations. When these directives were issued, EU financial markets were not as integrated as they are now, so policy makers did not focus on provisions directly aimed at safeguarding systemic financial stability.

The regulatory process in the EU has traditionally been slow, and homogeneous transposition of the agreed principles into the national regulations has proven difficult. ${ }^{10}$ As a result, different regulatory and supervisory requirements exist in the EU. For example, the EU directive on deposit guarantees gives member states latitude in regard to financing (ex ante

\footnotetext{
${ }^{6}$ In general, the process has been characterized by minimum interference with national regulators, subject to the restrictions imposed by the convergence process itself, which often allows a considerable scope for diversity in the transposition to national regulations (Nieto and Peñalosa, 2004).

${ }^{7}$ There are also non-prudential elements, such as limitations on government subsidies and other measures that protect domestic institutions.

${ }^{8}$ Directive 2006/48/EC of the European Parliament and of the Council of 14 June 2006 relating to the taking up and pursuit of the business of credit institutions (recast) Official Journal of the European Communities 30 June 2006, L 177 (the so-called Capital Requirement Directive). This Directive modifies Directive 2000/12/EC of the European Parliament and of the Council of 20th March, 2000 relating to the taking up and pursuit of the business of credit institutions. Official Journal of the European Communities, 25th May, 2000, L 126. The Capital Requirement Directive is being revised at the time of writing, in part to strengthen provisions on crossborder risks and their supervision.

${ }^{9}$ Directive 94/19/EC of the European Parliament and of the Council of 30 May, 1994 on deposit-guarantee schemes. Official Journal of the European Communities 31 May, 1994, L135/5

10 The Lamfalussy proposal (2001) aimed at increasing the speed and effectiveness of the regulatory process in the financial sector. It also aimed at better coordination of national regulations across countries and across sectors. These principles were enshrined in Directive 2005 /1/CE of the European Parliament and the Council of 9 March, 2005 L79.9.
} 
versus ex post funding), establishing the coverage level above the minimum (EUR 20,000), and administrating the schemes publicly or privately (Eisenbeis and Kaufman 2007, Garcia and Nieto, 2007, and Hoelscher, Taylor and Klueh, 2006).

The lack of full harmonization hinders coordination among regulators and other concerned agencies, and poses an additional challenge for information sharing. Moreover, it creates the potential for negative spill-overs, especially in the case of a bank failure. ${ }^{11}$ There may also be positive spill-overs from certain policies, such as those that promote greater stability or efficiency for the system as a whole. These positive spill-overs may be neglected by national decision makers, who therefore do not pursue them as vigorously as would be justified by their contribution to overall welfare.

The need for further integration and coordination was widely accepted already before the recent turmoil. The ECOFIN recognized that "financial stability in the EU is a common concern for all Member States and must be safeguarded on the basis of close co-operation.” ${ }^{2}$ Moreover, the Ministers of Finance agreed to develop the adequate policy instruments: “Arrangements and tools for cross-border crisis management will be designed flexibly to allow for adapting to the specific features of a crisis, individual institutions, balance sheet items and markets. Cross-border arrangements will build on effective national arrangements and cooperation between authorities of different countries.”13

The recent turmoil has shifted the debate dramatically. Starting in early October 2008, EU member countries effectively raced on another to extend deposit and other bank guarantees. Countries did not yet generally have to "ring fence" assets, but they strove to ensure that deposits and other financing remained available to their banks. Subsequently the EU countries began to act in a more coordinated fashion, including on deposit guarantees. ${ }^{14}$ In the context of a declaration by the G-8 and the IMF Annual Meetings, the EU member states coordinated the introduction of an extraordinary range of measures to support banks and guarantee claims on them. Meanwhile the European Central Bank had, in consort with other central banks, announced a reduction in policy interest rates and provided unlimited liquidity

\footnotetext{
${ }^{11}$ See for example Decressin, Faruqee and Fonteyne (2007).

12 International Monetary Fund (2008), Chapter IV, summarizes recent steps to enhance cross-border cooperation in supervision and financial crisis management, with special reference to efforts to introduce a joint mandate for supervisors to take spill-overs into account.

${ }^{13}$ Council of the European Union, Economic and Financial Affairs, 9 October, 2007.

14 The $2894^{\text {th }}$ Council of the European Union agreed an increase of the minimum coverage up to $€ 50,000$ among the measures adopted in order to offer immediate responses to the financial turmoil (Luxembourg, 7 October, 2008). Some countries had long had deposit guarantees above this level, and by early October other had introduced additional measures including, in some cases, full guarantees of a wide range of bank liabilities.
} 
to interbank markets. ${ }^{15}$ The longer term consequences of these dramatic events and the political economy effects had yet to play out at the time of writing.

\section{A MODEL OF SUPERVISORY AND DEPOSIT GUARANTEES COORDINATION}

We adapt the model of Dell'Ariccia and Marquez (2001) to allow for competition and cooperation in the provision of deposit guarantees. Each country's policy makers are concerned to promote the profitability of the financial sector and economic activity generally, but they also want to reduce the probability of having a financial crisis and its severity should one occur. To this end they use prudential regulation and supervision, and also deposit guarantees; each has its own costs and benefits, and thus an optimal amount to be supplied.

More prudential regulation and supervision $(S)$ in a country reduces the probability of a financial crisis occurring and its severity $(p)$. Note that regulation and supervision is taken in a broad sense to include, for example, transparency and governance rules, and also action by supervisors to enforce regulations such as requiring banks to take early remedial action once excessively risky behavior is detected. However, supervision is costly; the regulatory burden will impinge on financial sector profits or economic activity generally $(\Pi) .{ }^{16}$ Supervision is costly and creates a burden that has to be borne by someone in the economy. One may think of the burden as being borne by financial institutions, whose profits are reduced, but this is not necessary_ costs may be borne ultimately by depositors and borrowers.

Deposit guarantees $(D)$ give rise to a different sort of trade-off: having more generous guarantees is good when a country is faced with a crisis; there is less contagion among financial institutions, and depositors and others suffer lower costs from a disruption in the availability of liquidity. ${ }^{17}$ Even if deposit guarantees were in the first instance purely redistributive, spreading the burden of a bank failure would be beneficial if marginal utility

15 The announcement of the reduction of the interest rates in the main refinancing operations came together with the reduction in the corridor between the interest rate of the marginal lending and deposit facilities from 200 basis points to 100 basis points (see http://www.ecb.int/press/pr/date/2008/html/pr081008.en.html).

${ }^{16}$ To some extent good regulation and supervision may reduce the riskiness of banks and therefore lower their funding costs, which should raise the overall profits for the banking sector or the consumer surplus of the users of bank services. Even in this case, however, stricter regulation is likely to yield positive benefits only up to some point, and a net marginal cost thereafter. Furthermore, regulators may be "captured” by the banking industry or individual banks who bear all the costs but receive only part of the benefits, because some benefits accrue to users of bank services. For these regulators, marginal costs outweigh marginal benefits at a lower level of supervision than for a non-captured regulator. The equilibrium will necessarily be a region where, in the view of the decision-maker, supervision generates marginal costs.

${ }^{17}$ The availability of funds to depositors helps ensure that they are able to meet payment obligations, and funds can circulate to other banks, so that they do not become liquidity constrained in their lending. Where a guarantee is met through "purchase and assumption," another bank takes over deposits and a collection of loans and other assets from the failed bank. The second bank thereby provides continuity of financing for the assumed loans, thus reducing disruption to borrowers. 
of wealth is declining. However, deposit guarantees also give rise to moral hazard because the protection against down-side risk reduces depositors' incentive to monitor and control the behavior of bank managers; effectively, risk taking is subsidized, so more risks are taken. Because both the intensity of prudential supervision and the level of deposit guarantees affect the probability of a banking crisis, policies in these two areas interact.

It is convenient to describe the model in terms of deposit guarantees, but the same effects may be achieved by other mechanisms that effectively give creditors and borrowers prompt access to their funds and lines of credit. In particular, the prospect of a bail-out if a bank fails can induce moral hazard on the part of banks and those who invest in them, but a bail-out may be optimal ex post once a failure has occurred by minimizing liquidity and credit losses. ${ }^{18}$ In the context of this paper, deposit guarantees should be understood in the broad sense. Thus, the variable $D$ measures the credibly committed and expected amount of assistance; a country may have to deploy "commitment technology" to ensure that support for claimants on a failed bank is limited to the predetermined deposit guarantees. ${ }^{19}$ Nonetheless, the model focuses on the process of establishing persistent systems, institutions, and norms. While the argumentation would hold in a crisis situation, certain aspects of a crisis—such as flight to safety, which might abruptly redistribute liabilities—are not addressed.

Deposit guarantees are (initially) assumed to have no other costs, such as deadweight loss from levying premiums or taxes. Also, from a welfare perspective it does not matter in this model whether banks or taxpayers bear the costs of payouts should there be a bank failure.

It is further assumed that information between supervisor and deposit guarantee agency is perfectly symmetric, which, in practice, assumes that the later is either in the supervisory authority (as for example in Ireland, the Netherlands and Spain) or that they are closely related. ${ }^{20}$

In this section, we model the optimal level of prudential supervision and deposit guarantees in the case of policy makers that only consider the policy impact in their own country, and the case of policy makers that have similar preferences and consider the impact of their policies in a multi-country setting. Later we reflect on the case of policy makers that do not share the same preferences or where countries differ in other regards.

\footnotetext{
${ }^{18}$ An efficient resolution procedure may have the same effect without fostering moral hazard.

${ }^{19}$ Hence, we abstract from the kind of time-inconsistency and information-asymmetry problems discussed for example in Cihak and Decressin (2007).

${ }^{20}$ The asymmetries of information are particularly relevant in the case of deposit guarantee schemes that are privately managed, as it is the case in Germany.
} 


\section{Isolated country case}

To fix ideas it is useful to start with the case of a single country. The reduced-form and normalized equation of the welfare function to be maximized is

$$
W=\alpha \Pi(S)-(1-\alpha) p(S, D)(1-\beta D), \quad \Pi_{1}, p_{1}<0, p_{2}>0, \quad \alpha \in[0,1] .
$$

The parameters $\alpha$ and $\beta$ capture the weights attached to various elements that enter the objective function. A policy maker that attaches much importance to bank profitability and economic activity, as opposed to the probability of a financial crisis, will have a high $\alpha$. A government that attaches much importance to dampening the effects of a crisis through the provision of guarantees will have a high $\beta$.

The optimal level of supervision $\left(S^{*}\right)$ and deposit guarantees $\left(D^{*}\right)$ are implicit in the first order conditions:

$$
\begin{gathered}
W_{S} \equiv \alpha \Pi_{1}-(1-\alpha) p_{1}\left(1-\beta D^{*}\right)=0 \\
W_{D} \equiv-(1-\alpha)\left(p_{2}\left(1-\beta D^{*}\right)-\beta p\right)=0 .
\end{gathered}
$$

A subscript denotes a partial derivative with respect to the respective argument. The second order conditions are assumed to be fulfilled. Specifically, we will assume that second crossderivatives of $p\left(\right.$ ) such as $p_{12}$ (i.e., the off-diagonal terms in the matrix of second derivatives) are small relative to first derivatives and own-second derivates.

One can differentiate equations (2) and (3) with respect to $\alpha$ and $\beta$ and manipulate the equations to establish the sensitivity of the policy choices to the values of the parameters. Assuming that the second order conditions hold, it can readily be shown that the model conforms with certain intuitions: policy makers that give more weight to bank profits rather than stability would provide less supervision. If more weight is attached to reducing the effects of a crisis, more deposit guarantees are provided.

It is interesting to consider what happens if the amount of supervision differs from the optimal level — perhaps the country feels obliged to meet an international standard that is more rigorous than it would choose for itself_-or if the amount of deposit guarantees varies for extraneous reasons. To this end it is convenient to suppose for now that there is some additional adjustment parameter $\varphi$, representing, for example because there is an added cost to supervision. ${ }^{21}$ Thus, let the modified objective function be

\footnotetext{
${ }^{21}$ This “cost” might be negative if better supervision yields an additional benefit, perhaps because compliance with international standards enhances a country’s reputation.
} 


$$
W=\alpha \Pi(S)-(1-\alpha) p(S, D)(1-\beta D)-\varphi S, \quad \Pi_{1}, p_{1}<0, p_{2}>0, \quad \alpha \in[0,1] .
$$

Therefore, the modified first order condition is

$$
W_{s} \equiv \alpha \Pi_{1}-(1-\alpha) p_{1}\left(1-\beta D^{*}\right)-\varphi=0 .
$$

Clearly $d S^{*} / d \varphi<0$ (less supervision is provided when it is more expensive). Moreover, differentiating (2') and (3) with respect to $\varphi$ and rearranging yields

$$
\frac{d D^{*}}{d \varphi}=\frac{-W_{S D}}{W_{S S} W_{D D}-W_{S D}^{2}}=\frac{(1-\alpha)\left[p_{12}\left(1-\beta D^{*}\right)-\beta p_{1}\right]}{W_{S S} W_{D D}-W_{S D}^{2}}=\frac{-W_{S D}}{W_{S S}} \frac{d S^{*}}{d \varphi} .
$$

The second order conditions require that the denominator $\left(W_{S S} W_{D D}-W_{S D}^{2}\right)$ be positive, while $p_{1}$ is negative by assumption. Hence, if $p_{12}$ is not negative and too large in absolute value, the term $W_{S D}$ is positive and the expression $\left(-W_{S D} / W_{S S}\right)$ is negative. Under these conditions, a decrease in $S^{*}$ results in a increase in $D^{*}$. Intuitively, a country that subjects its banks to looser supervision has more need to guaranty its depositors against the consequences of bank failures. It is easy to show analogously that an extraneous decrease in $D$ results in an increase in optimal $S^{*}$, and vice versa. This result seems counter-intuitive: supervision is often thought of as required as an antidote to the moral hazard generated by deposit guarantees, so one might think that lower guarantees would lead to less supervision. However, one also needs to take into account the overall objective of protecting the economy from bank failures. Supervision and deposit guarantees are substitutes in the policy decision because supervision reduces the likelihood of a crisis, while good deposit guarantees reduce its cost.

\section{Two symmetric countries with spill-overs}

Suppose now that there are two countries, $i$ and $j$ whose banks and regulators have similar preferences in terms of efficiency and stability of their banking systems. Their financial systems are interlinked, such that a higher probability of crisis in one country will increase the probability of crisis in the other (for now, that is assumed to be the only linkage). The linkage could go through various channels: The two countries may be subject to common shocks, or be perceived to be subject to common shocks, so that confidence in one is undermined by bank failures in the other; banks in $i$ and $j$ may have interbank dealings with each other, so that the failure of a bank in $i$, for example, has a direct effect on the solvency and liquidity of banks in $j$; a bank in difficulties in $i$ may call in loans to corporations that also borrow from country $j$ banks, which consequently suffer a deterioration in portfolio quality; and some banks in one country may be subsidiaries of banks in the other and thus affected by strain on their parents.

The interlinkage creates positive and negative externalities in policy-making: better supervision in one country reduces the probability that it suffers a crisis, and therefore also the probability that the banks in the other country will be adversely affected; the probability 
of a crisis in the other country is reduced. In addition, a higher level of deposit guarantees in one country generates more moral hazard and thus a higher probability of a crisis, which increases the probability of crisis in the other country. The function $p($ ) describing the probability of crisis becomes, for country $i$,

$$
p^{i}\left(S^{i}, D^{i}, \gamma S^{j}, \chi D^{j}\right) \quad p_{1}^{i}, p_{3}^{i}<0, p_{2}^{i}, p_{4}^{i}>0
$$

and similarly for country j with the superscripts reversed. The parameters $\gamma$ and $\chi$ capture the degree of spill-over from country $j$ to country and vice versa; $\gamma, \chi \in[0,1] .^{22}$ The parameters $\gamma$ and $\chi$ could vary across countries, as could $\alpha$ and $\beta$. For now though attention focuses on the symmetric case: the spill-over parameters are the same across countries, and regulators have similar preferences in terms of banks’ profitability and financial stability, so

$$
\alpha_{i}=\alpha_{j}=\alpha \text { and } \beta_{i}=\beta_{j}=\beta \text {. }
$$

Given this symmetry in preferences, countries' policy makers will always behave in similar ways. Hence, in this case, if cooperation is worthwhile, it will always involve harmonization.

These spill-overs give rise to the possibility that uncoordinated action will be sub-optimal. In general, countries acting individually will provide less supervision than they would in the cooperative solution because they do not take into account the benefit for others. Furthermore, typically countries will compensate for the relatively low level of supervision by providing more deposit guarantees. Because the probability of crisis in country $i$ is raised by the risk of crisis in country $j, i$ will want to ensure that, should it be hit by a crisis, the effects are cushioned by generous deposit guarantees (viz. equation (4)). This cushioning is offset by the negative externality of deposit guarantees on the ex ante probability of crisis; the net effect will in general be to reduce on expected welfare from what it could be with full cooperation.

In the case of two symmetric countries with the possibility of spill-overs, there are three main possibilities: (i) each country continues to act in their individual national interest; or (ii) some policies are coordinated but others are not; or (iii) all policies are determined on a fully cooperative basis, taking both countries' welfare into account. Under the second possibility (ii), attention will focus on the case where supervision is coordinated but each country determines its own level of deposit guarantees. This dichotomy corresponds roughly to the current situation in Europe where, at least in some areas of prudential regulation (e.g., bank capital adequacy), the common standards are worked out in detail and practice is relatively

\footnotetext{
${ }^{22}$ Dell'Ariccia and Marquez allow for the possibility that the level of supervision in one country affects bank profitability in the other. Specifically, they assume that supervision is a cost burden that reduces a banking sector's competitiveness, and therefore higher supervision in one country raises bank profitability in the other. This assumption is not essential here but is discussed below.
} 
harmonized, while deposit guarantees are subject to only modest minimum standards, mainly on coverage, which are exceeded in many countries.

To formalize these intuitions, let the reduced form welfare function for country $i$ be

$$
W^{i}=\alpha \Pi^{i}\left(S^{i}\right)-(1-\alpha) p^{i}\left(S^{i}, D^{i}, \gamma S^{j}, \chi D^{j}\right)\left(1-\beta D^{i}\right) .
$$

The parameters $\gamma$ and $\chi$ capture the importance of the policy actions of country $j$ for country $i$; higher values for these parameters imply that the actions of country $j$ have larger spill-over effects on country $i$, and, as will be shown, variations in these parameters will affect optimal policy and the gains from cooperation. The welfare function of country $j$ is analogous. Welfare for the two counties together is taken to be the weighted sum of the two countries' welfare. Thus:

$$
\begin{aligned}
W= & \mu W^{i}+(1-\mu) W^{j} \\
& =\mu\left[\alpha \Pi^{i}\left(S^{i}\right)-(1-\alpha) p^{i}\left(S^{i}, D^{i}, \gamma S^{j}, \chi D^{j}\right)\left(1-\beta D^{i}\right)\right]+ \\
& (1-\mu)\left[\alpha \Pi^{j}\left(S^{j}\right)-(1-\alpha) p^{j}\left(S^{j}, D^{j}, \gamma S^{i}, \chi D^{i}\right)\left(1-\beta D^{j}\right)\right]
\end{aligned}
$$

where $\mu$ is the relative weight attached to country $i, \mu \in[0,1]$. This is the continuous and twice differentiable welfare function that is maximized with respect to all arguments in the fully cooperative case, and with respect to $S^{i}$ and $S^{j}$ only in the case of cooperation in supervision alone.

It is convenient to define the following terms:

$$
\begin{gathered}
A_{S}^{i} \equiv \alpha \Pi_{1}^{i}-(1-\alpha) p_{1}^{i}\left(1-\beta D^{i}\right) \\
A_{D}^{i} \equiv-(1-\alpha)\left(p_{2}^{i}\left(1-\beta D^{i}\right)-\beta p^{i}\right) \\
B_{S}^{i} \equiv-(1-\alpha) \gamma p_{3}^{j}\left(1-\beta D^{j}\right) \\
B_{D}^{i} \equiv-(1-\alpha) \chi p_{4}^{j}\left(1-\beta D^{j}\right),
\end{gathered}
$$

and analogous terms for country $j$ with the superscripts reversed. The terms $A_{S}^{i}$ and $A_{D}^{i}$ capture the marginal welfare for country $i$ of an increase in its own supervisory efforts or deposit guarantee coverage, respectively. The terms $B_{S}^{i}$ and $B_{D}^{i}$ capture the effects on country $j$ of these marginal changes in country $i$ 's policies. From the sign of $p_{3}$ it can be seen that $B_{S}^{i}$ is always positive, and from the sign and $p_{4}$ it can be seen that $B_{D}^{i}$ is always negative. 
The first order conditions $S^{i}$ and $D^{i}$ for in the various cases are as follows: ${ }^{23}$

(i) Non cooperative, where each country determines its supervisory and deposit guarantee policy separately to maximize its respective version of equation (6) in pursuit of individual national interests:

$$
\begin{aligned}
& A_{S}^{i}=0 \\
& A_{D}^{i}=0
\end{aligned}
$$

(ii) Supervisory cooperation, where each country determines its deposit guarantee policy separately to maximize its respective version of equation (6), but supervision levels in the two countries are chosen to maximize joint welfare (7):

$$
\begin{gathered}
\mu A_{S}^{i}+(1-\mu) B_{S}^{i}=0 \\
A_{D}^{i}=0
\end{gathered}
$$

(iii) Fully cooperative, where all four policy variables are chosen to maximize joint welfare (7):

$$
\begin{aligned}
& \mu A_{S}^{i}+(1-\mu) B_{S}^{i}=0 \\
& \mu A_{D}^{i}+(1-\mu) B_{D}^{i}=0
\end{aligned}
$$

Intuitively, the conditions under supervisory cooperation take into account the positive spillover of supervision from country to the other $\left(B_{S}^{i}\right)$ but the marginal cost per unit of supervision does not shift. ${ }^{24}$ Hence, more supervision is optimally chosen. Given more supervision, more deposit guarantees yield lower marginal benefit, so less is chosen.

The difference in marginal value of supervision between the non-cooperative and the supervisory cooperation cases can be illustrated by the Figure 1 below: ${ }^{25}$ The net marginal welfare of supervision is decreasing, but at any given level of $S$ and $D$ it must be higher when the benefit to the other country is taken into account. Therefore, the level of supervision that

\footnotetext{
${ }^{23}$ First order conditions for optimal $S^{j}$ and $D^{j}$ are analogous, with the superscripts reversed. Moreover, since policy makers in countries $i$ and $j$ are symmetric, at the optimum $S^{i}=S^{j}$ and $D^{i}=D^{j}$.

24 This would not be the case if cooperation was in itself costly, perhaps because of the supervisory resources that would have to be devoted to it.

${ }^{25}$ The additional marginal benefit need not be constant, so the curves are not necessarily parallel.
} 
solves the optimality conditions for supervisory cooperation must be higher than the optimum under non-cooperation.

Figure 1. Net marginal welfare from supervision (non-cooperation and cooperation only on supervision)

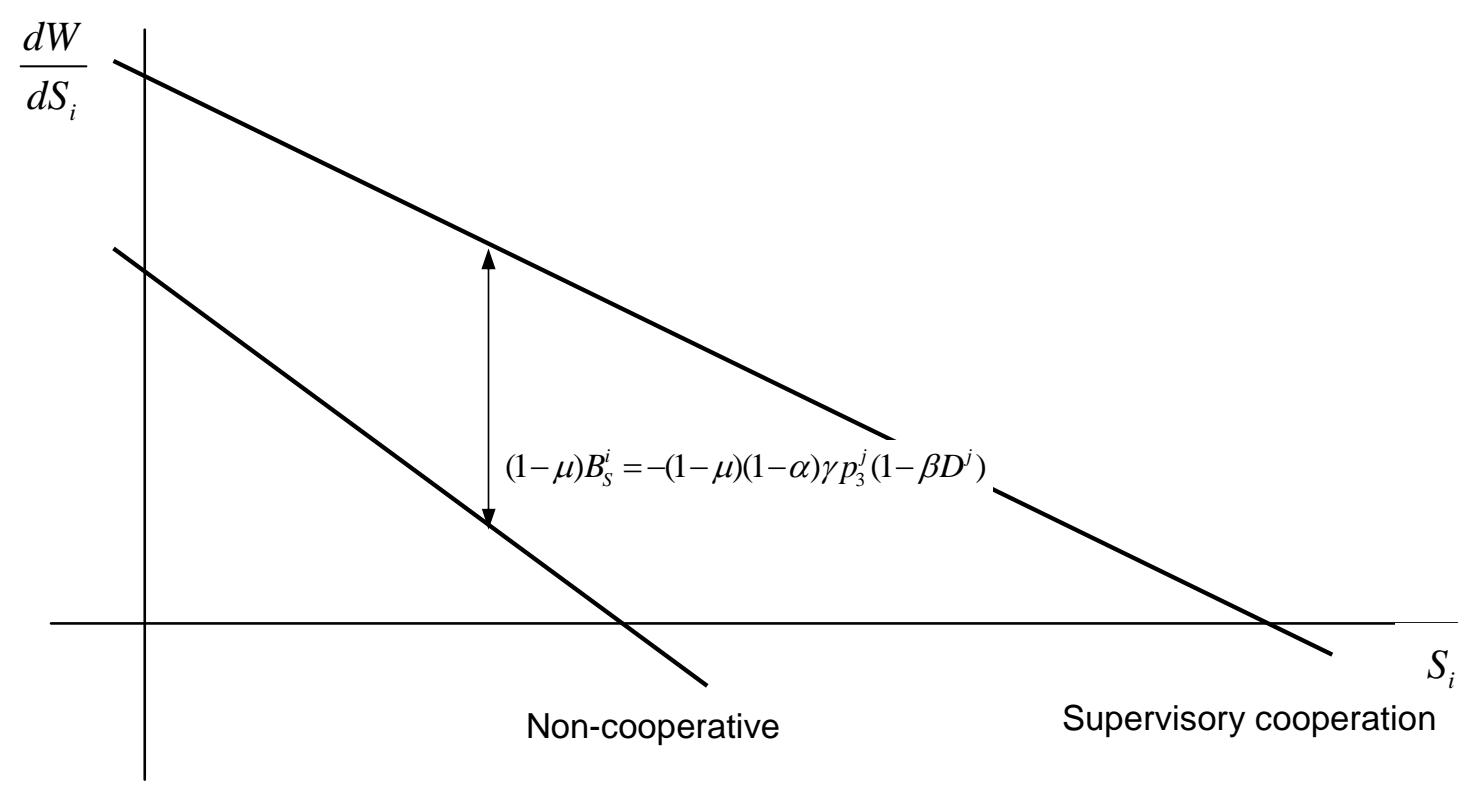

More formally, start from the non-cooperative values of $S$ and $D$, that is, those that satisfy conditions (12) and (13). These values would satisfy also condition (15) -which captures the lack of cooperation in deposit guarantees and is thus identical to (13) - but not condition (14) , which captures cooperation in supervision. Assume for now that the supervisory cooperation solution involved a lower level of $S$ in equation (14). ${ }^{26}$ Then, from equation (4), which shows how an exogenous increase in $S$ results in a decrease in $D$, in order to still satisfy the first order condition for no cooperation in deposit guarantees in equation (15), $D$ must be higher than in the non-cooperative solution. However, a lower level of $S$ makes $A_{S}^{i}$ positive (by the second order conditions of the non-cooperative solution) and $B_{S}^{i}$ is always positive. Moreover, higher $D$ will also increase both terms in condition (14). ${ }^{27}$ Hence,

\footnotetext{
${ }^{26}$ Since the countries are symmetric, a parallel argument applies to supervision and deposit guarantees in each country, and we can neglect country superscripts.

${ }^{27}$ Under the assumption that second cross-derivates are relatively small, the derivatives of $A_{S}^{i}$ and $B_{S}^{i}$ with respect to $D$ are both necessarily positive.
} 
condition (14) is not satisfied, and so the assumption must be false. Therefore, the supervisory cooperation solution must involve higher $S$ and lower $D$.

The conditions under full cooperation take into account both the positive spill-over of supervision $\left(B_{S}^{i}\right)$ and the negative spill-over of deposit guarantees $\left(B_{D}^{i}\right)$. Hence, under full cooperation there should be more supervision and even less deposit guarantees than in the other two cases.

A comparison can be made between the values of $S$ and $D$ that solve conditions (14) and (15) for cooperation only on supervision, and those that solve (16) and (17) for full cooperation that is analogous to the comparison made above related to conditions (12) and (13) and conditions (14) and (15). $B_{S}^{i}$ and $B_{D}^{i}$ are always positive and negative, respectively, and $A_{S}^{i}$ is decreasing in $S$ and $A_{D}^{i}$ is decreasing in $D$, so the only way to satisfy the fully cooperative conditions is with still more supervision and less deposit guarantees than under supervisory cooperation only.

The three cases can thus be arranged from high supervisory effort, relatively low deposit guarantees under full cooperation, to low supervisory effort and high deposit guarantees under no cooperation; cooperation only on supervision results in an intermediary case (Figure 2).

Figure 2. Optimal supervision and deposit guarantees (two symmetric countries with spill-overs)

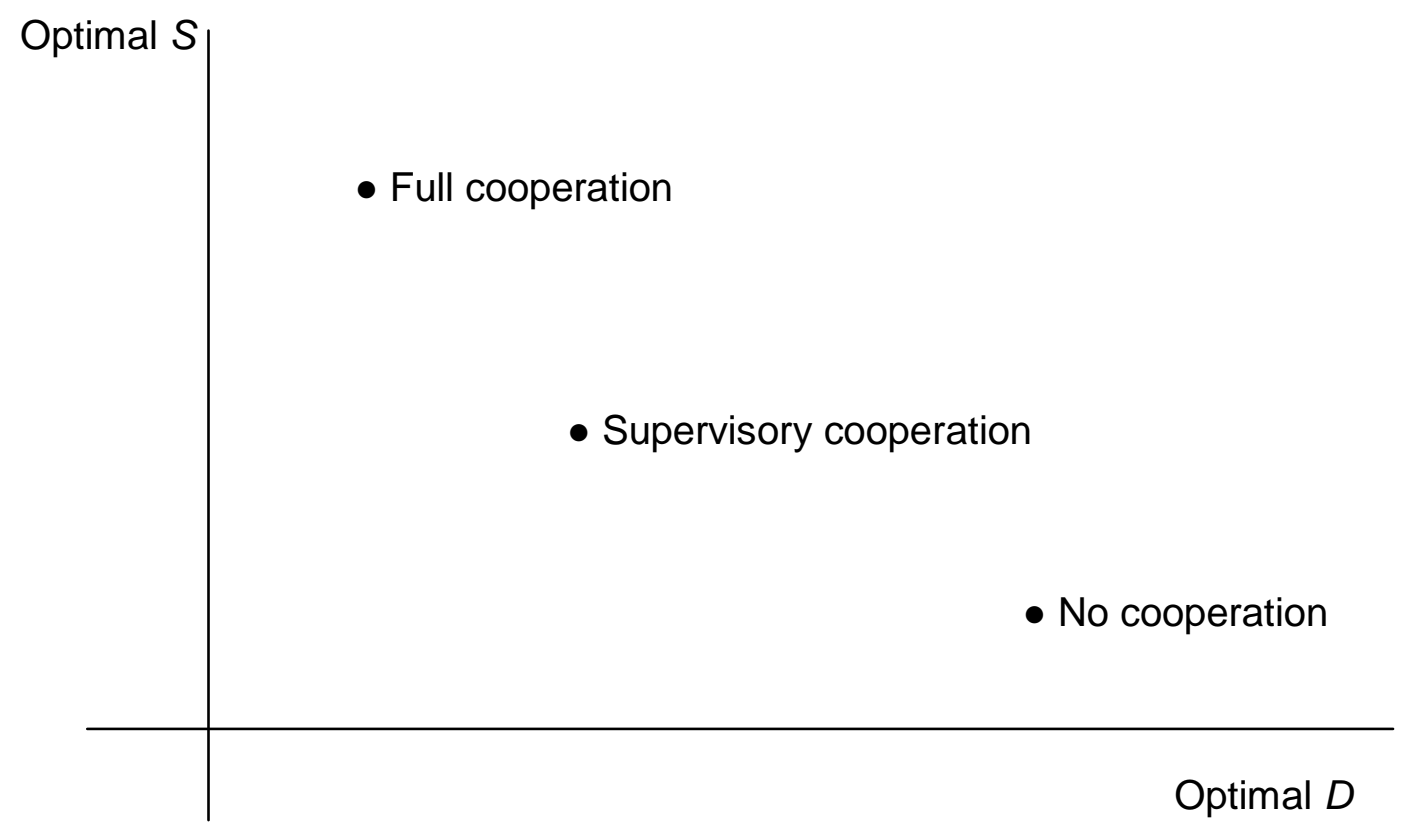


It is notable that countries have incentives to renege on commitments to cooperate; an enforcement mechanism is needed to realize gains from cooperation. Each country acting in a self-interested fashion would prefer the other to act cooperatively, while it spares itself the added costs. For example, if country $i$ chooses $S^{i}$ and $D^{i}$ according to the full cooperation conditions (16) and (17) and thus provides more supervision and less deposit insurance than it would otherwise, it reduces the probability of a crisis in country $j$ as well. Country $j$ therefore has an incentive to "free ride" by providing less of costly supervision unless cooperation is enforced.

Certain policy conclusions follow, at least for symmetric countries where policy makers have similar preferences in terms of profitability and safety and soundness under the assumption of symmetry and costless information and coordination:

- Full coordination of prudential supervision and deposit guarantees would result in the highest level of safety and soundness and involve the lowest provision of deposit guarantees.

- Cooperation in prudential supervision without deposit guarantees is better than no cooperation, but is sub-optimal compared to cooperation in both policy areas;

- Absent cooperation, countries tend to provide too little prudential supervision because they do not take account of the benefit to others. To compensate, countries provide more generous deposit guarantees than would be first best; and

- Agreement to cap deposit guarantees could be beneficial. Especially in the absence of full cooperation in prudential supervision-but also if only deposit guarantees is determined on a national level - each country may tend to provide excessively generous deposit guarantees, which protects its own depositors but has an adverse effect on financial stability everywhere. Capping deposit guarantees will induce countries to tighten supervision and thus move closer to the cooperative optimum.

The model can represent the shift in policies seen in the recent turmoil. It has been assumed that more generous deposit guarantees generate moral hazard, which increase the probability of crisis (so that $p_{2}>0$ ). However, once a bank is severely distressed but before it has been intervened, the availability of a guarantee may be perceived by policy makers as helping to prevent a run and therefore reduce the probability of collapse. This possibility can be represented by setting $p_{2}<0$. An examination of (13) or (15) and the definition (9) reveals that, if $p_{2}<0$, the optimal level of the deposit guarantee is unlimited; ${ }^{28}$ a full guarantee is provided when confidence in banks is severely undermined and deposit guarantee policy is not coordinated. When deposit guarantee policy is coordinated, the optimal policy is given

\footnotetext{
${ }^{28}$ Both the $p_{2}$ and the $-\beta p$ terms are negative, so formally there is no solution.
} 
implicitly by (17). Hence, if $p_{4}^{j}>0$ (the guarantee in one country decreases stability in the other), there could still be a solution with limited deposit guarantees because account is taken of the negative spillover.

\section{Asymmetric countries}

Banks and financial regulators may have different preferences in different Member States. Countries could be asymmetric in terms of the importance they attach to the two elements of the welfare function; their relative weight in a common welfare function ( $\alpha$ and $\beta$ ); the marginal effects of $S$ and $D$ in the bank profit and crisis probability functions due to different institutional arrangements; and the magnitude and sign of spill-overs $(\chi$ and $\gamma)$ due to the importance of their cross border activity.

The model has some plausible implications. A country that is strongly influenced by the condition of banks in the other country and thus by the other country's stability policies ( $\chi$ and $\gamma$ are large) will gain much from coordination. This effect can be seen by examination of equations (10) and (11), which define the marginal spill-over of supervisory and deposit guarantee policies, respectively. These expressions are larger in absolute magnitude, the larger are $\chi$ and $\gamma$. Hence, the change in the other country's behavior will be larger when cooperation is introduced, and the benefit for the "host" country will be larger.

The gain from cooperation will be especially large when the country receives a relatively high weight $(\mu)$ in the collective objective function that represents the decision making. In the European context, the financial systems of smaller countries are often dominated by subsidiaries of banking groups from larger countries, yet European institutions usually place importance on consensus, such that small countries have importance in decision-making that is disproportionate to their economic size. Hence, for these small countries would be rational to enhance supervisory cooperation.

Equations (10) and (11) also indicate that the marginal benefit of action by the other country will be small for a country whose policy makers give a high value to the preference parameter $\alpha$, that is, a country which places much weight on bank profitability. That country's welfare is not very sensitive to the reduced probability of a banking crisis that the other country's cooperative actions could achieve. Also, the higher is the value of $\beta$ (that is, a country whose policy makers place much weight on financial stability), the smaller is the magnitude of the marginal benefit of supervision by the other country: a high $\beta$ indicates that deposit guarantees is relatively effective in cushioning the effects of a bank failure. Hence, a diminution of the risk of failure induced by stronger supervision abroad does not contribute much to welfare.

The asymmetric case makes it interesting to consider the possibility of an additional type of equilibrium, namely, one in which both supervision and deposit guarantee levels are not only determined cooperatively, but must also be fully harmonized across diverse countries. Then, 
as in Dell' Ariccia and Marquez (2001), if countries differ sufficiently, a cooperative solution with harmonization may not be worthwhile. This harmonization solution improves on the uncoordinated, non-cooperative solution in that spill-overs are taken into account, but at the cost of imposing policies that are optimal for no one country. Various loci can be defined, along which countries are indifferent to cooperating or not. For example, if one country is very concerned about the profitability of its banking system and another attaches a great deal more weight to stability, they may find it impossible to find a cooperative solution with harmonization.

Despite the possible costs of full harmonization, some cooperation (in the form of minimum or maximum standards) is in general worthwhile for each country: starting from the noncooperative equilibrium, a little cooperation small movement in a policy variable in the direction of cooperation incurs zero net marginal cost to the originating country, but yields a positive marginal benefit for the other country in terms of positive spill-overs. Suppose for example that country $i$ attaches more importance to banks' profitability than country $j$, so that $\alpha^{i}>\alpha^{j}$. In this case, country $i$ tends to have weaker supervision and more generous deposit guarantees than country $j$. Consider the non-cooperative equilibrium, where countries determine policy settings according to equations (12) and (13). From this starting point, a marginal increase in supervision by country $i\left(d S^{i}\right)$ and a marginal decrease in deposit guarantees $\left(-d D^{i}\right)$ leave $i$ 's welfare unchanged, since $i$ has maximized its welfare with respect to these variables (the first order conditions imply that the welfare function is locally flat). However, using equation (6) applied to country $j$, these marginal adjustments change $j$ 's welfare by

$$
-\left(1-\alpha^{j}\right)\left(\gamma p_{3}^{j} d S^{i}-\chi p_{4}^{j} d D^{i}\right)
$$

where $\gamma p_{3}^{j} d S^{i}$ represents the spill-overs of weaker supervision of country $i$ into $j$ and $\chi p_{4}^{j} d D^{i}$ represents the spill-overs of higher deposit guarantee coverage in $i$ into country $j$. The marginal adjustment is certainly positive given the assumptions that $p_{3}<0$ and $p_{4}>0$. Hence, it should always be possible to agree on a minimum prudential standard of supervision that is at least slightly binding on the weakest supervisor, and a maximum level of deposit guarantees that is at least slightly binding on the most generous deposit guarantee scheme.

\section{Modifications}

It is easy to introduce additional features into the model:

- Deposit guarantees could generate additional costs, which might be borne by banks. It is straightforward to add a $D^{i}$ term into $\Pi^{i}$ with a negative partial derivative (and similarly for country $j$ 's welfare function). The analysis would go through substantially unchanged, except that there would be less generous deposit guarantees. Alternatively, 
deposit guarantees could reduce banks' funding costs and thus be a net benefit, especially if a part of the contingent costs are borne by the government, as is often the case. The second possibility would increase the over-provision of deposit guarantees in the noncooperative solution. In addition, the provision of deposit guarantees to banks in one country might give then a competitive advantage or disadvantage (for example, in gaining market share) relative to banks in the other country, and thus raise or lower their profits. Experience from the recent turmoil suggests that generous deposit guarantees are seen as a competitive advantage in times of stress.

- Supervision in one country (say, $i$ ) could be costly to banks in the other country (say, $j$ ) if they operate in $i$ and are subject to its supervision. ${ }^{29}$ Introducing a term $S^{i}$ into the function $\Pi^{j}$ with a negative partial derivative would not greatly alter the analysis, although cooperation might then entail less supervision if the negative spill-over onto profits were strong enough. However, it could also be the case that supervision in $i$ has a positive effect on profits of country $j$ banks by raising the costs of their competitors from $i$ (as assumed by Dell'Ariccia and Marquez), in which case the incentives to undersupervise and provide more deposit guarantees are enhanced in country $j$.

- The objective function of supervisors may diverge from that of the providers of deposit guarantees. For example, the supervisor and/or the deposit guarantee provider may have bureaucratic incentives to expand their mandates or avoid what may be seen as embarrassing failures. Alternately, one or the other may be more prone to capture by industry interest groups, fiscal interests, or political groups, in which case it will be important to determine who bears the cost of deposit guarantees. ${ }^{30}$ However, the qualitative results presented here should be robust to such complications. For example, suppose that the deposit guarantees provider is especially concerned about the expected cost of deposit guarantee payouts. This concern might be captured by including an additional term in the deposit guarantees provider's objective function, which might become

$$
W^{i D}=\alpha \Pi^{i}\left(S^{i}\right)-(1-\alpha) p^{i}\left(S^{i}, D^{i}, \gamma S^{j}, \chi D^{j}\right)\left(1-\beta D^{i}\right)-v p^{i} D^{i}
$$

where the superscript $\mathrm{D}$ indicates that the objective function applies to the deposit guarantee scheme, $v$ is a parameter, and $p^{i} D^{i}$ is the expected deposit guarantee payout. It is easy to show that less generous deposit guarantees are provided than the supervisor would like. Yet, the tendency for cooperation to lead to increased supervision and decreased generosity of deposit guarantees would remain, and indeed the deposit guarantees provider would welcome the move.

\footnotetext{
${ }^{29}$ For example, due to the cost of reporting requirements or higher supervision fees.

${ }^{30}$ Hardy (2006) applies the concept of regulatory capture to banking supervision.
} 
- Costs to cooperation and coordination could be made explicit. Because the model has no informational or organizational costs, full coordination is always optimal and can be no worse than decentralized decision making (so long as harmonization is not imposed on highly asymmetric countries). It could however be that supervisors and deposit insurers know their own local banks best, and therefore uncoordinated decision making results in greater informational efficiency that partly offsets the welfare cost of neglecting externalities. Some limit on cooperation would then be optimal. Note, however, that this argument applies to situations in which one country supervises or provides deposit guarantees for (branches and subsidiaries of) banks from another country. ${ }^{31}$ It does not apply to situations in which the spill-overs are channeled directly through the banks, for example because of interbank lending or contagion affecting investor confidence in different countries. In such situations, national agencies would deal just with their own banks, so informational asymmetries should not matter.

\section{Application to the Policy Debate in the EU and Conclusions}

EU policy makers' agenda has been overturned by the recent financial turmoil. Attention had been focused on coordination between home and host country supervisory authorities (including in a crisis situation), and the updating of certain directives covering prudential policies and the safety net. Revision to common standards for deposit guarantees is on the agenda, in part provoked by the recent failure of some banks, but concrete proposals of a comprehensive reform have not been issued at the time of writing. Policy makers had already become more committed to improving national arrangements and cooperation mechanisms between safety net regulators in the member countries.

One major project concerns the revision and implementation of the Capital Requirement Directive that transposes Basle II in the European context. ${ }^{32}$ Two issues under discussion are particularly relevant to our analysis: first, the need to reduce the number of national discretions in the transposition of the Directive into the national laws of the member states; and second, to secure a consistent and transparent implementation of Pillar 2 in the so-called Supervisory Review Process in the EU context. Both represent policy areas in which lack of cooperative behavior between prudential supervisors and lack of coordination of supervisory action that might cause negative externalities in the EU.

\footnotetext{
${ }^{31}$ In the EU, a host country may provide deposit guarantees to branches of foreign banks only as "topping- up" of the home country coverage.

32 Directive 2006/48/EC of the European Parliament and of the Council of 14 June 2006 relating to the taking up and pursuit of the business of credit institutions (recast) (Official Journal of the European Union L177/201, 30 June, 2006).
} 
Regarding the options and national discretions, the European Commission, in its call for technical advice to the Committee of European Banking Supervisors (CEBS), mentioned that "the European Banking Committee has agreed that mutual recognition of national discretions should not be seen as an optimum or definitive solution. This might result in embedding national discretions in Community legislation and might, under certain circumstances, lead to regulatory arbitrage.” There are 141 areas of national discretion in the transposition of the Directive that are covered by the principle of mutual recognition. They are aimed at securing the autonomy of the national authorities. ${ }^{33}$ Similarly, the principle-based character of Pillar 2 requires consistency and transparency in its implementation, and calls for the convergence of supervisory practices and tools throughout the EU. The Committee of European Banking Supervisors (CEBS) has issued a set of guidelines so called Supervisory Review Process (SRP) for the implementation of Pillar 2. However, they do not remove supervisory discretion as to when to intervene, nor do they establish minimum supervisory actions, opening the possibility that one country supervisor could exploits discretion to the detriment of others.

The need to improve deposit guarantees in Europe is becoming more widely recognized at a time when it seems that even very large financial institutions risk suddenly running into liquidity and eventually solvency difficulties. However, current approaches to deposit guarantees are very diverse, and there is no consensus about what an ideal scheme would look like. Moreover, the possibility of “topping-up” (whereby a bank with branches in several countries may offer better deposit guarantees in some than in others, or than its competitors) raises the issue of arbitrage opportunities for banks, which may decide to opt in or out of them according to the present or future foreseeable cost of such arrangements. This behavior may have financial stability implications. Yet, policy makers have paid little or no attention to the interrelation between the level of deposit guarantees and supervision: the closest they have been to this issue, has been considering the need of risk based premium contributions to the deposit guarantees. Moreover, premiums have been based only on the riskiness of individual banks and volume of deposits, without regard to the quality and effectiveness of prudential supervision, not to mention the potential negative externalities for other member states in the case of cross-border banks. ${ }^{34}$

\footnotetext{
${ }^{33}$ The national discretions refer, among others, to the list of own funds, the scope of the application of the Directive and other technical issues such as risk weights. For a detailed list see: http://www.cebs.org/Advice/documents/Industryquestionnaireonoptionsandnationaldiscretions.xls
}

The creation of CEBS in the context of the Lamfalussy architecture was aimed at closing the gap between national practices and therefore achieving a full scale convergence but its limited powers would limit its results.

34 The potential negative and positive spill-overs of prudential supervision are, to a certain extent, taken into account in the risk based capital of consolidated banking groups. 
This paper attempts to contribute to the theoretical underpinnings of reforms in these areas. In particular, we examine the optimal level of prudential supervision and deposit guarantee regulation in a multi-country integrated banking market, where policy-makers have either similar or asymmetric preferences regarding profitability and stability of the banking sector.

Policy conclusions of our paper include the following:

- The first best approach would involve the simultaneous strengthening of prudential supervision and limiting depositor protection. However, each country has an incentive to "free ride" on the strengthened supervision of others, so an enforcement mechanism such as mutual evaluations is needed.

- Strengthening coordinated prudential regulation and supervision is valuable even if deposit guarantee schemes are not well coordinated. Stronger supervision (which can be taken to include enforcement action that requires imperiled banks to take remedial action long before they are insolvent) will reduce the need for deposit guarantees, and help induce countries to limit protection to depositors and other bank creditors. Hence, implementation of the Capital Requirement Directive that reduces the scope for national discretions, and limiting supervisory discretion at the national level are high priorities.

- Consideration should be given to establishing not only a minimum level of deposit guarantee coverage, but also a maximum level. In this connection, deposit guarantees should be taken to include de facto protection of creditors and not only official schemes. In addition, deposit guarantee risk premiums could be set taking into consideration the potential negative externalities of the supervisory discretion in the case of cross-border banks.

Further research could consider model specifications that account for the asymmetric and costly information for supervisors and deposit guarantee regulators. Another avenue for future research would be the analysis of the consequences of the institutional allocation (centralized versus decentralized) of prudential supervision and deposit guarantees on the supervisors' incentives for forbearance, which may depend in part on the varying degree of accountability to different sets of tax payers. 


\section{BIBLIOGRAPHY}

Barth, James R., Gerard Caprio Jr., and Ross Levine (2006), Rethinking banking regulation: till angles govern, Cambridge University Press, New York.

Cihák, Martin and Jörg Decressin,” The Case for a European Banking Charter,” International Monetary Fund Working Paper WP/07/173.

Decressin, Jörg, Hamod Faruqee, and Wim Fonteyne (2007), Integrating Europe’s financial markets, International Monetary Fund, Washington D.C.

Dell’Ariccia, Giovanni, and Robert Marquez (2001), “Competition Among Regulators,” International Monetary Fund Working Paper WP/01/73.

Demirgüç-Kunt, Asli, and Enrica Detragiache (2002), “Does Deposit Insurance Increase Banking System Stability? An Empirical Investigation,” Journal of Monetary Economics 49(7), pp. 1373-1406.

Demirgüç-Kunt, Asli, and Harry Huizinga (2004), "Market discipline and deposit insurance,” Journal of Monetary Economics 51(2), pp. 375-99.

Demirgüç-Kunt, Asli, Edward J. Kane, and Luc Laeven (2006), "Determinants of Deposit Insurance Adoption and Design,” World Bank Policy Research Paper No. 3969, Washington D.C.

Eisenbeis, R. A. (2006), 'Home Country versus Cross-Border Negative Externalities in Large Banking Organization Failures and How to Avoid Them,” Federal Reserve Bank of Atlanta Working Paper 2006-18, October.

Eisenbeis, R. A. and George G. Kaufman (2006), “Cross-Border Banking: Challenges for Deposit Insurance and Financial Stability in the European Union,” Federal Reserve Bank of Atlanta Working Paper 2006 -15a (revised January, 2007).

Freixas, X. (2003), “Crisis Management in Europe,” in J.J.M. Kremers, D. Schoenmaker and P.J. Wierts, (eds.),Financial Supervision in Europe, Edward Elgar, pp. 102-19.

Garcia, Gillian G. H. (1999), “Deposit insurance: a survey of best practices,” IMF Working Paper WP/99/54, Washington, DC.

Garcia, Gillian G. H., and Maria J. Nieto (2007), "Preserving Financial Stability: A dilemma for the European Union,” Contemporary Economic Policy Vol. 25, No. 3, pp. 444-58.

Hardy, Daniel C., “Regulatory Capture in Banking,” IMF Working Paper WP/06/34, Washington, DC. 
Hoelscher, David S., Michael Taylor, and Ulrich H. Klueh (2006), “The Design and Implementation of Deposit Insurance Systems,” IMF Occasional Paper No. 251, Washington D.C.

Holthausen, Cornelia, and Thomas Rønde (2005), “Cooperation in international banking supervision,” Center for Economic Policy Research Discussion Paper Series No. 4990.

International Monetary Fund (2008), “Euro Area Policies-Selected Issues—2008 Article IV Consultation,” (http://www.imf.org/external/pubs/ft/scr/2008/cr08263.pdf).

Kane, Edward J. (2002), "What Kind of Multinational Deposit-Insurance Arrangements Might Best Enhance World Welfare?" Keynote Address: APFA/PACAP/FMA Finance Conference.

Laeven, L. (2004), “The Political Economy of Deposit Insurance”. Journal of Financial Services Research 26(3), pp. 201-24.

Nieto, Maria J., and Garry Schinasi (2007), “EU Framework for Safeguarding Financial Stability: Towards an Analytical Benchmark for Assessing its Effectiveness,” International Monetary Fund Working Paper WP/07/260, Washington D.C.

Nieto, Maria J., and Juan Peñalosa (2004), “The European Architecture of Regulation, Supervision and Financial Stability: A Central Bank Perspective,” Journal of International Banking Regulation, 5(3), 2004, pp. 228-42. 